\title{
Political Science as a Contest of Perspectives
}

\author{
Jeffrey C. Isaac
}

In n 1987 I left New York and moved to Bloomington, Indiana, to join the political science department of Indiana University, Bloomington. While I had done my graduate work at Yale University under the supervision of Bob Dahl, one of the leaders of "the behavioral revolution," it was only upon my arrival at Indiana that I became fully initiated into the world of professional political science. One of the first things I noticed was that many of my senior colleagues were frequently talking about "The Review." "Did you see that new piece in The Review?" "Are you sending your paper to The Review?" "He published in The Review last year. That's almost as good as his book publication, and it should nail his tenure case."

"The Review." What is this Review of which they speak, I wondered? I was familiar with The Review of Politics. Not that. I was familiar with The Review of Radical Political Economics. Surely not that. The New York Review of Books? Hardly. "The Review" was, of course, the American Political Science Review, the gold standard of American political science and indeed, presumably, of political science writ large. The journal of political science, to which all others were secondary. The apotheosis of American political science as a discipline. The "flagship" of the research armada.

The American Political Science Review has occupied this status ever since its founding in 1906. But as the discipline grew it also outgrew this fine journal's suzerainty. By the millennium, a wide range of questions were raised about the journal, questions that can be boiled down to one core question: was the journal big enough, and broad enough, to fully encompass and represent the range of approaches, styles, and genres of research and writing characteristic of the discipline roughly one hundred years after its founding? The answer of many to this question was a loud "no!" And so APSA took notice. And so was born a new journal, whose very name announced its broad mission: Perspectives on Politics. From its start, in 2003, Perspectives has sought to incorporate a wide range of approaches to political science methodology, research, and scholarly writing, and a range of different genres of writing: peer reviewed scholarly research articles, programmatic and reflective essays, book reviews and review essays and symposia.
When we took over the journal in 2009, we sought to make more explicit the inclusive mission of the journal by branding the journal as A Political Science Public Sphere, as a way of emphasizing the importance of dialogue and debate across conventional divides within the discipline, and the importance of publicity more generally. We sought to make more explicit the different genres of writing that we would publish and the forms of review and editing to which each of them is subject; to make clear that the journal's approach to scholarly research articles is that the very best scholarship is perspectival, and offers some new way of understanding some important political problem that emerges from ongoing scholarly debates and must proceed by critically engaging these debates; and to make clear that as a general journal of political science, we recognize that there are different kinds of scholarly conversations and research "products," and different moments within the research process itself, and that this particular journal furnishes a space for this range of serious scholarly inquiry.

At the same time, we have also tried to make clear that the primary mission of the journal is to feature political science perspectives on politics. We have thus sought to be very ecumenically "problem-centered," and to avoid many interesting discussions that were largely about methodology rather than about politics by way of applying methodology. There have been some exceptions to this "rule," and the most notable was the journal's stance towards "DA-RT," a stance which involved both an editorial policy-refusal to sign onto the "DA-RT" statement and the articulation of a less restrictive and voluntary policy —and an editorial essay entitled "For a More Public Political Science," explaining this editorial policy and linking it to a broader statement about the purposes of political science. This statement struck a nerve. According to the 2016 Publication Report of Cambridge University Press, it is the second "most popular" piece published by any APSA journal in the past five years, having received over 19,000 online full-text views (the most "popular" article was also published in Perspectives, Martin Gilens and Benjamin Page's "Testing Theories of American Politics," which has received over 88,000 full-text views!). The journal's "position" on DA-RT represents a major 
intervention in a major ongoing disciplinary discussion. Quite obviously some colleagues agree with this position and others do not. The wide and rapid circulation of my editorial is not a sign of widespread agreement. But it is a sign that what the journal stands for is important to many people.

All the same, the controversy about DA-RT was not initiated by Perspectives, and the journal's editorial position was a response to an initiative started by others that promised to dramatically alter the publishing landscape and had much momentum and institutional support. Even here, the journal has sought less to "take a stand" in ongoing methodological culture wars in the discipline than to resist methodologically-obsessed arguments and to defend the importance of scholarly spaces that are broad, eclectic, and pluralistic. Our editorial approach has always sought to focus on political themes and to feature excellent research and writing done from a variety of subfield and methodological perspectives. This is why we have featured many substantive themes - gender and politics, the politics of financial crisis, the politics of labor, the politics of violence, etc.- - but we have never featured discussion of methodology.

This issue of Perspectives is an exception to this rule. The reason for this exception is fairly straightforward: a number of articles and essays were moving forward in our editorial queue that raised methodological questions, and in the past year or two I have commissioned reviews of a number of interesting and important books dealing with methodological concerns. So the time seemed right to publish these things together, to dedicate our special book review section to the books on methodology, and to make explicit a theme that has always been central to this journal's distinctive mission: the importance of methodological pluralism as both an epistemic value and a way of promoting collegiality and mutual respect among colleagues who typically hold very different ideas about how to practice political science.

Our issue contains a number of articles and essays that exemplify a pluralism of methods. Sarah Parkinson's "Money Talks: Discourse, Network, and Structure in Militant Organizations" offers an interpretive account of intra-organizational divisions and generational differences in the Palestinian Fatah movement that centers on the analysis of "informal discursive practices-e.g. gossip, jokes, complaints, storytelling" and their political meanings. Based on extensive ethnographic field research, the article represents a contribution to empirical scholarship on militant organizations, but also reflects on the importance of qualitative approaches: "Immersion in these social networks is a crucial means of assessing how organizational hierarchies, institutions, and roles operate in 'real life."' This approach provides incomparable insight into the meanings that people associate with their affiliations and the ways that social practices structure intra-organizational relations. By highlighting insider views, performances, and understandings of membership, it also privileges interlocutors' experiences of the organizational worlds that they inhabit rather than relying on external categorizations." Nick Robinson and Marcus Schulzke's "Visualising War? Towards A Visual Analysis of Videogames and Social Media" discusses the increasing "visuality of politics [which] has become more pronounced with the explosive circulation of images, particularly on and through social media," and offers a "mixed method" approach to the study of videogames and game advertisements, in which qualitative and interpretive approaches are joined to a "Military Videogame Advertisement (MVA) dataset" lending itself to quantitative analysis. [It is worth noting that both of these articles contains links to extensive online Appendices in which the authors voluntarily share qualitative data and analytics in order to facilitate further scholarly discussion and debate.]

The issue also contains many pieces that reflect on the theme of methodological pluralism.

Bartholomew Sparrow's essay on "Why Would a Political Scientist Write a Biography?" reflects on the reasons why he wrote The Strategist: Brent Scowcroft and the Call of National Security, a biography of Lt. Gen. Brent Scowcroft, and also on the value of biographical writing for political science scholarship. [It is perhaps worth noting that the book was published by PublicAffairs Books, and that it received wide attention among foreign policy elites, was featured on C-Span, and was reviewed in the New York Times, the Wall Street Journal, and the Washington Post.] As Sparrow comments: 'Biography fulfills several of political science's objectives as a discipline: it studies 'important' issues of politics and government; it provides the 'thick description' necessary for making causal inferences; it addresses the 'agency versus structure' issue; it constitutes both a 'single case study' and a 'single outcome study'; it is falsifiable; and it can explain politics and government to those outside political science and beyond the academy."

Evan Lieberman's Reflections essay, "Can the Bio-Med Research Cycle be a Model for Political Science?" nicely raises the theme of pluralism by suggesting that one way to promote a more capacious appreciation for different kinds of research is, taking biology as a model, to consider them as different moments in a "research cycle" that together drive the growth of knowledge. Because his argument is both programmatic and provocative, we invited a group of scholars to comment on it from a range of perspectives: Colin Elman (along with Colleen Dougherty Burton), a major figure in recent discussions about both qualitative methods and the DA-RT initiative; John Hibbing, a major contributor to a sociobiological approach to political science that draws heavily on biology; Kirstie McClure, a political theorist who has reflected on these issues as a scholar but also as one of the long-term principal editors of the American Political Science Review while it was edited at UCLA; and Tulia Faletti, who has written extensively on the themes of historical institutionalism and process tracing.

This issue's lead article, Matthew A. Kocher and Nuno P. Monteiro, "Lines of Demarcation: Causation, Design-Based 
Inference, and Historical Research," addresses these issues head-on, by offering a critique of some of the limits of the trend towards "design-based inference" in comparative politics. As they write, this approach "extends the logic of experiments to observational research, judging its reliability based on how closely it approximates to the experimental ideal. Specifically, DBI prescribes that researchers seek to identify 'natural experiments': instances in which a natural or social process has assigned units to distinct conditions in a way that is as 'good as random." Kocher and Monteiro argue that this approach mistakenly treats experimental research as a "gold standard," and assigns idiographic and historical forms of knowledge to a secondary status, even though judgments about whether the distribution of experimental conditions is "as good as random" must rest on such historical knowledge. As they write: "if validating a natural experiment requires trust in the ability of qualitative evidence to establish the causal processes through which the data was generated, there is no good reason for natural experiments to be considered epistemically superior to historical research. To the contrary, the epistemic status of natural experiments is on a par with that of the historical research on which their validation depends. They are two modes of social-scientific explanation, each with its own pros and cons; neither is privileged." Kocher and Monteiro develop their argument through a critique of an important and widely-cited APSR article, "Political Devolution and Resistance to Foreign Rule: A Natural Experiment," by Jeremy Ferwerda and Nicholas L. Miller. Both sets of authors center their arguments in part on competing interpretations of the "Line of Demarcation" separating Nazi occupied France and Vichy during WWII, and whether this line established a "natural experiment" capable of generating broader understandings of the relationships between the devolution of authority and patterns of resistance to authority.

Kocher and Monteiro claim that the Line of Demarcation did not constitute a natural experiment, and that "the French Resistance carried out more attacks near the $\mathrm{LoD}$ in the directly-occupied zone because the double-track railways used intensively by the Germans to move troops and materiel were more abundant there than they were in the Vichy zone." Their critique of Ferwerda and Miller's interpretation of the "Line of Demarcation" separating Nazi occupied France and Vichy is grist for the mill of ongoing scientific inquiry and argumentation. At the same time, the "line of demarcation" that is their more profound object of criticism is the line of demarcation drawn by many who wish to demarcate the experimental analysis of causation, and perhaps the quantitative analysis of causation more generally, from more ethnographic, idiographic and interpretive forms of inquiry, and to judge the former as more authentically "scientific" than the latter. Kocher and Monteiro insist that this line of demarcation is arbitrary and misleading, and that it would be better to underscore the complementarity of these approaches. As they conclude: "Either both historical research and natural experiments are inside the line of demarcation delimiting the scope of scientific discourse, or they are both outside."

These discussions and debates will continue, as they should. They are featured in our book symposium on Dawn Langan Teele's edited volume, Field Experiments and Their Critics: Essays on the Uses and Abuses of Experimentation in the Social Sciences, which sets up a wide-ranging dialogue about the relative strengths and limits of field experiments, and experiments more generally, in political science, with contributions by Henry Brady, Yanna Krupnikov, Jessica Preece, Peregrine Schwartz-Shea, and Betsy Sinclair. They are also featured in our symposium on Josiah Ober's The Rise and Fall of Classical Greece, which treats ancient Greece as a kind of natural experiment, in which a range of similarly sized and situated city-states differed, in a quasi-random manner, only in terms of their governing institutions and in terms of a set of outcomes whose variation can be explained with reference to these differing institutions.

Ober is a classicist, and in his earlier books for which he is most famous, such as Mass and Elite in Democratic Athens (1989), Political Dissent in Democratic Athens (2008), he centered his analysis of ancient Greek and especially ancient Athenian democracy mainly on the analysis of ancient rhetoric and ancient political philosophy. In this book he employs the tools of contemporary "new institutionalism" in order to analyze the ancient Greek world and to contribute to a broader, trans-historical social theory centered on the dynamics of collective action and the importance of democracy as a system of pragmatic experimentation and social learning. Ober's book raises important historical, normative, and methodological issues that are taken up by our symposiasts. Whereas Frederika Maria Carugati assesses Ober's account in light of recent advances in classics scholarship, and raises some of the issues discussed by Kocher and Monteiro regarding the "randomness" of the "natural experimental treatments" in classical Greece, Melissa Schwartzberg considers the way Ober's empirical analysis supports normative arguments on behalf of democratic political equality. Daron Acemoglu, James Robinson, and Barry Weingast praise Ober's move beyond "the traditional humanities tools" long employed to understand classical Greece, contending that "Ober gives us the first integrated view of this new understanding, using all the tools and concepts of social science. But the road Ober travels is not a one-way street of modern social science being introduced to studies of the classical world. Ober has also brought Classical Greece into the modern world of social science as a case for study in the fields of comparative politics and economic development." Yet Arlene Saxonhouse, whose own work relies largely on those "traditional humanities tools" commonly employed by historians of political thought, is reluctant to so quickly center the discussion of classical Greece on the contemporary concerns of "new institutionalists" seeking to resolve socalled "Hobbesian" problems of order. She thus cautions: "I am certain that Ober understands Aristotle's deeper 
commitments and cares for them in his diatribe against Leviathan. My minor worry is that the Aristotelian concern with human flourishing may disappear behind the attention to economic flourishing that can easily be captured by the raw numbers controlling the book's central thesis. The Greek efflorescence gave us Aristotle. We should not ignore the insights Aristotle offered about the true nature of human flourishing. The worry about Leviathan may lie deeper than the conditions for economic wellbeing; it may come from what we learn courtesy of just those philosophers who flourished during the efflorescence of ancient Greece."

As Saxonhouse's comment indicates, these discussions about the value of historical modes of inquiry, and what Max Weber long ago called "the methodology of the social sciences," raise a perhaps more fundamental question: the relationship between those forms of knowledge conventionally called "the humanities" and "social science." In American political science, this question has long been linked to a second: what is the proper role or place of "political theory" or "political philosophy" as a form of inquiry, in a discipline devoted to the scientific study of politics. This theme is taken up in two "Reflections" essays that were submitted, independently, within days of each other: Joshua Foa Dienstag's "On Political Theory, the Humanities, and the Social Sciences" and Joshua Mitchell's "Reflections on Political Theory and the Humanities in a Global Age." Both pieces articulate, and reflect, a concern share by many self-identified political theorists: that they occupy a precarious and increasingly vulnerable place within a broader discipline that places an increasing premium on positivistic forms of methodological rigor. Both Dienstag and Mitchell seek to engage this concern and to articulate the value of the kinds of questions and approaches characteristic of political theory as a subfield and as a mode of inquiry. At the same time, they do this in rather different ways. Dienstag wants to defend a version of political science, and indeed of American political science, in which political theory holds an important place: "It can be very pleasant, as political theorists, especially for those of us housed in political science departments, to think of ourselves as lonely humanists surrounded by formulaic social scientists whose rigid application of mechanistic models drains all the nuance out of politics-nuance which we, trained so differently, are especially capable of appreciating... But as pleasant and self-gratifying as this story is, it is hardly true. American political theory, as a branch of political science, is equally and perhaps more clearly descended from the continental tradition of Staatswissenschaft that dominated German universities in the nineteenth century and the American universities that increasingly imitated them... So I think an honest look at our history, and even at our own syllabi, reveals that political theory is not simply a humanistic practice misplaced in political science by an accident of history — a fantasy which, I should point out, is as comforting to some of our more statistically-minded colleagues as it is to us (in a different way, of course, in their case-as a grounds for exclusion!). What has happened instead is that the bounds of science have been repeatedly moved and narrowed in the last century so that broad theories of the state and the textual interpretation required to understand debates about them are things that many political scientists no longer consciously contemplate as a part of their scientific method-although in practice, of course, they employ both all the time." Dienstag supports an integrated political science that asks big questions in a variety of ways: "What I am trying to stress here is that seeing the kinship of political theory to the humanities is not primarily a matter of replacing moral and scientific questions with aesthetic or rhetorical ones, but instead of blending both kinds into a 'discipline of questioning' that is holistic in its scope." Such an approach can accommodate "the interpretation of old texts," but also celebrates "recent attempts by political theorists to study things like policing, immigration, and incarceration, for example."

Mitchell, on the other hand, expresses "doubt that political science and political theory should continue to live under the same roof," arguing that the fate of political theory is linked to a broader crisis of the humanities and to a "changing institutional landscape, which has also helped bring political theory to its current dead-end within the discipline of political science." What follows is a critique of the modern American university: its function as a means of credentialism in an increasingly anti-intellectual world ("it is tempting to say that what occurs in our many of our universities nowadays amounts less to higher education than to Higher Certification, perhaps even Higher Stupification"); the insularity and hyper-professionalism of its disciplines; and the ascendancy of a "hermeneutic of suspicion" that ill prepares students for citizenship in an increasingly interconnected world. Mitchell proposes a new discipline, which he calls "comparative canonical inquiry," centered on a "sorely needed conversation about the range of durable self-understandings within civilizational domains." And he concludes with a provocation: "My unabashed proposal, then, is that political scientists be granted the divorce they secretly wish. I suspect that they will soon enough suffer the same fate the discipline of sociology did when, in the 1980s, unsure of themselves because they were not a natural science, sociologists largely abandoned their rich and fertile nineteenth century canon in exchange for rational choice theory. Now a faint echo of its former self, sociology wanders in the dark, hobbled and unable to formulate interesting questions because it is unable to draw from the wellspring of canonical authors it has repudiated .... The subfield of political theory can stay where it is, and as it is, and slowly wither. The humanities can continue to bet the farm on the hermeneutics of suspicion. Alternatively, under the rubric of comparative canonical inquiry, they can together find their 
voice anew, in response to the geo-political moment that now urgently challenges us all."

I think it is fair to say that this proposal cuts against the wager upon which this very journal rests-the possibility that a reinvigorated political science discipline can promote new and important conversations that reach across increasingly hidebound subfield and methodological divides, and generate new insights about things that matter. New perspectives on politics. At the same time, the debate between Dienstag and Mitchell, and also the challenge both present to political science as a whole, is precisely the kind of conversation that our discipline needs to have, and that this journal is designed to promote.

Our issue also contains a number of terrific pieces on the complex ethical relationships between the political scientist and the political world s/he seeks to understand.

Romain Malejacq and Dipali Mukhopadhyay's article announces this theme with its very title: "The 'Tribal Politics' of Field Research: A Reflection on Power and Partiality in $21^{\text {st }}$-Century Warzones." The piece offers a sustained reflection on the challenges and opportunities of doing field research under the conditions of "new wars" in conflict zones such as Afghanistan, Somalia, and the Turkey-Syria borderland. Malejacq and Mukhopadhyay argue that "those who conduct fieldwork in conflict-ridden environments must recognize their own positionality as marked by limited power and unavoidable partiality," and that the diverse, often indeterminate "power dynamics between researchers and researched are especially complicated in conflict zones, where violence is a key currency in all relations. There is a persistent 'potential for danger' that comes with research about and in the midst of violence." They argue that in such settings it is essential to develop networks of support, and "this means belonging to one or more tribes, micro-systems of networks and individuals who recognize themselves as linked to one another and can offer a researcher access, support, and protection." At the same time, they note that these connections both enable and constrain the scholar's activity and access and sometimes even his or her very perspective: "Field sites are not free and open markets for the trading of allegiances; instead, the researcher's agency is limited. In the midst of contentious politics a researcher may be unable to move as she pleases from one network to the next; and previous affiliations will shape her own profile and path going forward. In this sense, the concept of tribe reflects the limits on a researcher's power and impartiality."

These issues of positionality and power are also discussed in Lee Ann Fujii's "Politics of 'The Field," a review essay on Diana Kapiszewski, Lauren Morris MacLean, and Benjamin L. Read's Field Research in Political Science: Practices and Principles. They are also central to our symposium on Robert Vitalis's book White World Order, Black Power Politics: The Birth of American International Relations. Vitalis presents a critical disciplinary history of the field of international relations, arguing that the interconnections between imperialism and racism were "constitutive" of international relations scholarship in the U.S. since the turn of the $20^{\text {th }}$ century, and that the perspectives of a generation of African-American scholars that included W. E. B. Dubois, Alain Locke, and Ralph Bunche were equally constitutive of this scholarship-by virtue of the way the emerging discipline sought to marginalize these scholars. Our symposium includes commentaries on this argument, and its implications for the discipline today, by Neta Crawford, Lilly Ling, Daniel Nexon, and Meera Sabarantnam. (This symposium is usefully read alongside the symposium on Laura Sjoberg's Gendering Global Conflict: Towards a Feminist Theory of War in our March 2014 issue.) Our issue contains a book review essay on this theme by Robert Vitalis: "The Racial Origins of American Social Science," a discussion of Aldon Morris's The Scholar Denied: W. E. B. Du Bois and the Birth of Modern Sociology.

It also contains two more substantial "Reflections" essays on the congenital blindspots of our discipline. David Lake's "White Man's IR: An Intellectual Confession" is a powerful and deeply personal reflection, written by a major scholar who also happens to be the current President of the American Political Science Association, and it offers what its title announces-a commentary on the racial constitution of international relations scholarship. And Kennan Ferguson's essay considers precisely the question announced in its title: "Why Does American Political Science Hate American Indians?" Ferguson's piece actually cuts to the heart of American political science as a discipline, and indeed to the heart of American self-understandings about politics, and so we have made it the centerpiece of a symposium, with commentaries by Daniel Carpenter, Paul Frymer, Lauren Morris MacLean, Joely Proudfit, David E. Wilkins, and Franke Wilmer.

In an interview almost a quarter-century ago, the social theorist Pierre Bourdieu offered a comment about his own discipline that is equally applicable to our own: "What distresses me when I read some works by sociologists is that people whose profession it is to objectivize the social world prove so rarely able to objectivize themselves, and fail so often to realize that what their apparently scientific discourse talks about is not the object but their relation to the object."

Perspectives on Politics is a scholarly journal of political science. Its primary aim is to feature the very best political science articles, essays, and reviews about politics as judged according to the highest standards of scholarly research and writing. The pieces published in this issue demonstrate that serious political science scholars can be disciplined in their analysis of the political world while also being reflexive and ethically attentive to their place in the political world.

\section{A Statement on the Recent Election}

Every four years there is a U.S. Presidential election. And every four years the things we do as political scientistsresearch, teaching, public commenting_-achieve a heightened 
relevance in American public life. The recent election is no exception. At the same time, it has brought to the fore several important questions that cut to the heart of the work that we political scientists do:

- Is there a tension between a civic and an ethnic or racial conception of nationhood and political identity?

- How deep does gender run as source of political identification, and political resentment, in our society?

- Is it possible, or desirable, to reinforce borders and attempt to make nation-states impermeable to "outsiders?"

- In a political and a moral sense, what does it mean to speak of "insiders" and "outsiders" in our highly interconnected world?

- Has U.S. politics reached an unprecedented level of polarization and, if so, what is the axis of polarization: race, class, party ideology and identification, geography, or belief in liberal democracy itself?

- Is the two-party system in the U.S. facing a serious crisis?

- Has electronic and social media, and questions of privacy, security, and hacking, assumed an unprecedented role in our politics?

- Has the tension between the Electoral College and the idea of one person, one vote-the core principle of democratic legitimacy_reached a point of serious concern?

- What is the proper relationship between elections and other forms of civil society activity, including protests, in a liberal democracy?

Recent events render these questions especially urgent. Addressing and answering them is the "bread and butter" of what we do, as scholars, teachers, and civic professionals.

Perspectives on Politics is a journal committed to featuring work that deals with big questions such as these. And in recent years, we have featured all of these themes in our pages. If you go back and look at the way we have constructed our issues around themes, and look at the titles of the Introductions I have written, you will see precisely these themes being discussed. The discussions are serious and scholarly, and the discussants are political scientists who come at these questions from a wide range of intellectual perspectives. The work that we publish is not politically defined. It is intellectually defined by its contribution to ongoing scholarly discussion and debate. In our articles and essays and book reviews we feature a range of topics and perspectives across the political spectrum. What defines the "political science public sphere" we foster is a commitment to vigorous and free professional political science inquiry about political problems and questions that really matter.

Vigorous and free scholarly inquiry is and ought to be the primary value served by scholarly publications such as ours. In this sense we are "above" politics, even if most of the work that we publish has political implications - and because we publish many different authors, there are many different implications on offer. At the same time, all scholarly disciplines and publications are part of the broader public world, and the value of vigorous and free scholarly inquiry depends on a broader set of values that are protected in most free societies. Without the protection of these values, journals such as ours, and disciplines such as ours, could not flourish.

Values central to the scholarly enterprise include:

1. Academic freedom: at the heart of all scholarship and teaching in the contemporary university is the freedom of scholars to pursue the topics that they choose to pursue, to research and write about these topics in the ways that seem most appropriate to them as autonomous individuals and as professionals, and to publish their ideas, and share their knowledge and perspectives in the classroom, without fear of institutional punishment because of the content of their ideas.

2. Broad freedom of speech and expression in society at large: in our dealings with our research subjects, our students, broader reading publics, and each other, we must be free to share our ideas and to gather to discuss these ideas, without fear of governmental monitoring, harassment, or punishment.

3. Professional autonomy: in our teaching, scholarly publication, and academic and community service, we must be free to determine our own intellectual agendas, and to judge ideas, policies, and people based on their scholarly merits and not on the national, sexual, racial, or ethnic origins of the speaker.

4. Worldliness: vigorous and free scholarly inquiry knows no bounds. To be a scholar and a university teacher and professional, in any domain, is to participate in a global republic of letters. Political science, like all scholarly disciplines, requires the free movement of ideas across national borders, and the free movement of the scholars and intellectuals-including both faculty and students- who are the carriers of these ideas.

5. Education: the purpose of the research and teaching that we do is to develop and share knowledge and thereby to educate the students in our classrooms and universities and the broader public as well. Education can only flourish in a climate of intellectual openness and respect for the opinions and the status of every teacher and every student.

Freedom of inquiry is a freedom, and as a freedom its continuation depends on its vigorous exercise.

In the weeks, months, and years ahead journals such as Perspectives on Politics: A Political Science Public Sphere will have an important role to play as spaces of scholarly sharing and critical reflexivity and as examples of vigorous, free, and undaunted discussion of the political challenges before us and our world.

-Jeffrey C. Isaac, Editor in Chief

November 15, 2016 


\title{
The Centrality of Books to Political Science and to Perspectives on Politics
}

\author{
By Jeffrey C. Isaac, Editor in Chief
}

Almost half of every issue of Perspectives is dedicated to our Review section. This structure of the journal is something that we inherited, for when Perspectives was created, it was decided to move the APSA book reviews, which had previously been published in the APSR, to Perspectives, and to open up the new journal to a range of writing formats.

We inherited this structure, but we also embraced it.

Indeed, I assumed the position of Editor in Chief of the entire journal after having served for four years as the Book Review Editor under the editorship of my predecessor, Jim Johnson. During my tenure as Book Review Editor we made a conscious decision to innovate with this section, by creating new formats-Critical Dialogues, Book Symposia, different kinds of thematic review essays, and Review Editor Introductions highlighting common themes - and trying to make the "back end" of Perspectives a space for lively conversation across conventional subfield and methodological divides in the discipline. These innovations were announced and explained in my inaugural editorial statement, "A Statement from the Book Review Editor" (Perspectives on Politics, March 2006, pp. 3 4 ), and the approach to the journal's treatment of books has remained true to the perspective outlined in that public text.

When I was offered the editorship of the entire journal in 2009, I agreed to accept this position on the basis of a clearly defined vision that was grounded in our experience with the Review section, and I was committed to editing the entire journal as a whole. My reason was straightforward: I believed that the journal was a unique and precious intellectual resource, and I was-and am-deeply committed to placing it on the strongest possible footing as a venue that features a wide range of political science perspectives and formats in a genuinely integrated way. It is surely possible for the two "ends" of the journal to be edited by separate individuals, working together in a collaborative fashion. But I was and am strongly committed to the idea that the two ends can and should be integrated into a single whole; that each "end" should in fact have diverse formats, so that in fact the journal would be much more complicated and interesting than a simplistic oppo sition of "articles" and "reviews" implies; and that these formats should speak to one another.

This vision was endorsed by the APSA officials - the search committee chaired by Rogers Smith, APSA President Peter Katzenstein, and the APSA Council-who unanimously supported my appointment.

When my editorial team took over the entire journal in 2009, we "branded" the journal as "A Political Science Public Sphere," and worked hard to nurture synergies between the research articles and essays published in the journal's "front end" and the reviews and book discussions published in its "back end" (this vision was announced in "Perspectives on Politics: A Political Science Public Sphere," my editorial statement published in the March 2010 issue, and now printed at the beginning of each issue). My staff and I have devoted enormous energy to this approach to the journal, with the strong support of our dedicated Editorial Board and with the support of the APSA Council. These efforts were recognized by the 2011 Performance Review Committee that recommended the extension of our editorial tenure. But in my view the most important "recognition" of this approach is the fact that we continue to enjoy the enthusiastic participation of many hundreds of authors and reviewers every year, and to produce a publication that includes a wide range of excellent contributions across a range of formats.

At the heart of the journal as it has come to be structured, read, and appreciated within the profession, is the deliberate effort of our editorial team to discern, nurture, and publicize complementarities, synergies, and broad thematic interests that might otherwise be insufficiently recognized by our increasingly specialized academic life. Our entire range of formats is dedicated to this end. We have nurtured the production of research articles that are rigorous, rigorously peer-reviewed, and at the same time are written and framed more broadly than conventional research articles. We have nurtured a range of conversations about political science books, and promoted conversations between our articles and our book reviews and essays. These connections have been essential to our vision of "a political science public sphere." 
Readers of the journal will be familiar with this range of formats, and with their complementarities:

- Research articles

- "Reflections" essays

- Book Review Essays

- Book Symposia

- Book Critical Dialogues

- "Undisciplined" Reviews and Review Essays (featuring reviews of books from other disciplines)

- A special thematic Book Review section in each issue

- Standard single, double, and triple Book Reviews

Readers will also be familiar with the ways that we have sought to plan our production schedule so we can package writings in these formats together thematically, and highlight these themes in my Editor Introductions. These efforts draw scholarly and public attention to broad and interesting themes. And by promoting broad and relevant scholarly discussion, they also help us reach beyond the discipline, and to gain the attention, and sometimes even the involvement, of journalists, policy intellectuals, and sometimes even a broader reading public. Recent examples include:

- Our June 2012 issue featuring work on violence

- Our September 2012 special $10^{\text {th }}$ Anniversary issue on "Post-Katrina New Orleans and the Politics of Reconstruction"

- Our March 2013 issue featuring work on "The Politics of Inequality in the Face of Financial Crisis"

- Our June 2013 issue featuring work on "Nature and Politics"

It is sometimes overlooked how central our Book Review section is to these efforts. But even a casual perusal of any recent issue of Perspectives will remind colleagues of the centrality of books.

I have been a professional political scientist for over thirty years. We are all well acquainted with the still widely accepted notion that book review assignments are convenient means of getting a free book that you want to read and of dashing off a thousand-word commentary during one's breaks from "real" research and writing. For the past eight years we have worked tirelessly, and successfully, to counter this unfortunate notion.

Books are important, and so serious intellectual attention to them is important.

While promptly published scholarly articles are also important, the book format remains the only format that allows scholars, in every field and from every perspective, to take the time and space to develop an argument in depth. Books are at the heart of political science. Important books help to create new research agendas. The names Almond or Dahl or Katzenstein or Putnam or Skocpol or Ostrom or Riker or Olson or Fenno or Mansbridge or Aldrich do not evoke journal articles. Each evokes an important book, and typically more than one of them. Every year many hundreds of new political science books containing new political science perspectives are published. We know this. The Book Exhibit at the annual APSA conference is one of the main attractions for almost everyone.

These books seek and deserve more than mere citation and more than glorified "Book Note" type reviews. They deserve serious discussion in a serious scholarly context. They deserve well-written reviews that are carefully edited by editors who work with reviewers, and prompt them to think a bit more broadly, and to view their book reviews as real scholarly engagements. Such reviews do much more than publicize and provide short cuts to books that readers might not otherwise know about. They engage the books and make them really a part of serious scholarly dialogue.

But there is something else: these reviews make their authors part of seriously scholarly dialogue.

Most of our colleagues do not work at research-intensive universities. Most of them spend most of their time teaching, often with heavy loads, either as tenured or tenuretrack professors at teaching institutions, or as adjuncts and part-time academic workers. For many of our colleagues, the chance to write a fine book review, and to have it seriously engaged by an editor, and to have it published in a "flagship research journal," is one of the only significant opportunities they may have to write and to publish in a given year.

Every year Perspectives on Politics publishes hundreds of book reviews written by a very wide range of scholars with a wide range of institutional affiliations. We are very serious about the range and diversity of the contributors to our book review section. One reason is because it allows our journal to reach broadly, and to include many of readers as contributors. This "community-building" function of Perspectives is very important, for a scholarly community ought to be linked by scholarly conversation in which each participant has genuine opportunities to speak as well as to listen and to be an author as well as a reader.

But this kind of inclusion is also important in an epistemic sense. For it "enforces" a breadth of scholarly perspective, and brings expert discourses into conversation with more generalist perspectives, to the benefit of the kind of true critical engagement that is the heart of the scientific enterprise. In this sense, every 1500 word book review that we publish is much more than a professional "service"; it is a serious contribution to scholarship and to the development of scholarly research. And the publication of these reviews in a flagship journal of political science, alongside rigorously peer reviewed research articles, essays, symposia, and dialogues, highlights their importance.

We are excited about the range of formats contained within Perspectives, and the way that they work together to project a vision of scholarly and intellectual seriousness. We believe that in this age of specialization, "modularity," 
and almost costless digital creation and circulation of texts, it is important for an intellectually serious political science discipline to have at least one broad, integrated, and intellectually serious journal that features a range of perspectives, formats, and scholars.

We believe, in short, that it is important for there to be a political science public sphere.
We are also grateful to the many colleagues who support us in these efforts, and who embrace the chance to be active participants in and contributors to the journal and its many formats. We continue to receive a growing number of article submissions, and we have many exciting book review special features planned in the coming issues. As we move forward, we welcome your ideas and suggestions. 